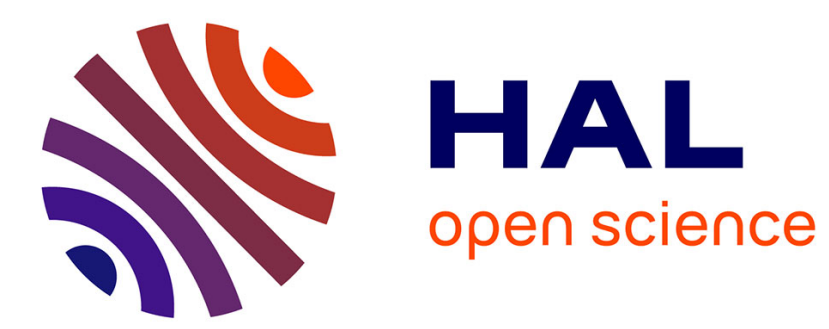

\title{
Fracture behaviour of steel 20 MnMoNi 55 under stress wave loading
}

\author{
R. Clos, U. Schreppel, P. Veit, U. Zencker, E. Specht
}

\section{To cite this version:}

R. Clos, U. Schreppel, P. Veit, U. Zencker, E. Specht. Fracture behaviour of steel 20 MnMoNi 55 under stress wave loading. Journal de Physique IV Proceedings, 1994, 04 (C8), pp.C8-717-C8-722. 10.1051/jp4:19948110 . jpa-00253352

\section{HAL Id: jpa-00253352 https://hal.science/jpa-00253352}

Submitted on 1 Jan 1994

HAL is a multi-disciplinary open access archive for the deposit and dissemination of scientific research documents, whether they are published or not. The documents may come from teaching and research institutions in France or abroad, or from public or private research centers.
L'archive ouverte pluridisciplinaire HAL, est destinée au dépôt et à la diffusion de documents scientifiques de niveau recherche, publiés ou non, émanant des établissements d'enseignement et de recherche français ou étrangers, des laboratoires publics ou privés. 


\title{
Fracture behaviour of steel 20 MnMoNi 55 under stress wave loading
}

\author{
R. Clos, U. Schreppel, P. Veit, U. Zencker and E. Specht \\ Institut für Experimentelle Physik, Technische Universität "Otto von Guericke", 39106 Magdeburg, \\ Universitätsplatz 2, PSF 4120, Germany
}

\begin{abstract}
Résumé - Le comportement d'initiation de la rupture de l'acier à petits grains 20 MnMoNi 55 sous charge par ondes de contrainte fut analysé au moyen de barres de Hopkinson dans la gamme de températures de 50 à $20^{\circ} \mathrm{C}$. Si les températures sont inférieures à $20^{\circ} \mathrm{C}$ la rupture est provoquée par clivage; $K_{I d}$ descend et tombe jusqu'à la ténacité à rupture. Par contre, sous température ambiante une croissance stable de la fissure apparaît avec un $\mathrm{J}_{\mathrm{i}}$ proche de la valeur d'initiation statique de l'intégrale de J. L'analyse de la configuration des pointes de fissure permet de fair reconnaître qu'une croissance stable de fissure est conditionnée par les processus aléatoires suivants déclenchés simultanément: génération de microfissures locales empêchées de se propager; neutralisation de ces pointes de fissures isolées et déformation des liaisons de matériaux le long du front des pointes de fissure.
\end{abstract}

Abstract - Crack initiation in fine grained $20 \mathrm{MnMoNi} 55$ steel has been investigated under stress wave loading conditions in the temperature range from $-50^{\circ} \mathrm{C}$ to $20^{\circ} \mathrm{C}$ by a loading setup similar the "Split Hopkinson Pressure Bar" technique. For temperatures up to $20^{\circ} \mathrm{C}$, fracture occurs by cleavage and $\mathrm{K}_{\mathrm{Id}}$ approaches and falls below the reference fracture toughness, while at room temperature stable crack growth occurs with a $J_{i}$ close to the static initiation value of the J-integral. The analysis of the crack tip configuration suggests that stable crack growth is the result of the following simultaneously induced stochastical processes: generation of constrained local microcracks, blunting of the individual crack tips and the deformation of material bridges at different regions along the crack tip front.

\section{EXPERIMENTAL METHODS}

The loading setup is shown in Fig. 1a. It consists essentially of a gas gun, a long input bar (circular cross section, diameter $20 \mathrm{~mm}$, length about $1 \mathrm{~m}$ ) and the fatigue precracked specimen. The specimen is pressed slightly against the bar in such a way, that its right-hand end can be considered as a free end within the investigated time range. By the impact of the projectile a pressure pulse of short duration is generated in the input bar. The pulse propagates through the bar and the specimen. At the free end of specimen it is reflected as a tensile pulse, which interacts with the crack and can cause crack propagation depending on its amplitude. Usually a finite amount of crack growth is produced. The pulse is measured with a coaxial capacitive gauge and recorded with a digital oscilloscope (the time resolution 
is usually $0.1 \mu \mathrm{s}$ ). With this type of stress wave loading crack tip loading rates $\dot{\mathrm{K}}_{1}$ up to $10^{7} \mathrm{MPam}^{1 / 2} / \mathrm{s}$ can be attained [1].

The structure and configuration of cracks in the precracked and stress pulse loaded specimen were studied by light microscopy. For this purpose the specimens were cut into slices (Fig. 1b). The 3Dcrack profile was reconstructed by careful step-by-step sectioning parallel to the $x-y$ plane with a step size of $\Delta z \approx 4 \mu \mathrm{m}$. The density and arrangement of the precipitates and dislocations were studied by transmission electron microscopy quantitatively. Some of the loaded specimens (with finite crack growth) were finally fractured in liquid nitrogen and the fracture surfaces were investigated by scanning electron microscopy. The quantitative analysis was carried out with a digital image analysis system. The J-integral versus time curves and the development of the plastic zone at the stress pulse loaded crack tip were determined by 3D-FE/FD-calculations (Fig. 2). Details of the experimental methods are given in [2].

\section{RESULTS AND DISCUSSION}

The chemical composition of the investigated material is shown in table 1 . It is a bainitic-martensitic steel (grain size $8 \mu \mathrm{m}$ ) with a small content of ferrite (grain size $16 \mu \mathrm{m}$ ) and banded structure. Nearly globular carbides (about $0.2 \mu \mathrm{m}$ in diameter) were found along the grain boundaries and within the boundaries (about $30 \mathrm{~nm}$ in diameter). The original microstructure is dominated by dislocation cells (about $0.6 \mu \mathrm{m}$ in diameter).

A typical fatigue crack path is shown in Fig. 3. The frequency and length of the secondary microcracks are influenced by the morphology of grains.

The fracture behaviour in the applied loading rate range from $5 \cdot 10^{6}$ to $10^{7} \mathrm{MPam}^{1 / 2} / \mathrm{s}$ indicates a strong temperature dependence. For temperatures to $20^{\circ} \mathrm{C}$ crack propagation occurs by cleavage (see Fig. 4) and the dynamic fracture toughness $\mathrm{K}_{\mathrm{Id}}$ approaches and falls below the reference fracture toughness ( $\mathrm{K}_{\mathrm{rR}}{ }^{-}$ curve in Fig. 5). In the temperature range from $-50{ }^{\circ} \mathrm{C}$ to $-35{ }^{\circ} \mathrm{C}$ (the lower temperature corresponds to $\mathrm{RT}_{\mathrm{NDT}}$ ) the fracture toughness is insignificantly above the static values. The mechanism of crack propagation is dominated by cleavage connected with fields of microcracks around the propagated crack tip (see Fig. 3). Above $-20^{\circ} \mathrm{C}$ the crack propagation is dominated by ductile fracture initiation on a macroscopic scale.

The results of the quantitative metallography and fractography at the loading temperature $20^{\circ} \mathrm{C}$ (Fig. 6) show that already at low pulse stresses a rugged crack front (see Fig. 7) is formed. The microscopic crack growth mechanism at increasing J-integral consists of the following successively and simultaneously occuring processes:

i) Generation of isolated small microcracks along the front of the mean crack. The propability of generation as well as the area and direction of microcracks depend on the local microstructure. Material bridges (ligament) between these "structural" microcracks hinder the growth of the microcracks (constrained growth, $\mathrm{J}_{i}^{\mathrm{e}}$ in Fig. 8).

ii) Plastic deformation of the material bridges and blunting of the individual crack tips. This process dissipates energy and the work hardening inside the plastic zone increases the yield stress.

iii) Ductile fracture of the ligament between the blunted microcracks. The large plastic strains developed ahead of the crack tip initiate necking. Nucleation, growth and coalescence of microvoids during necking generate small dimple bands. 
A temporarily closed crack front is necessary for macroscopic crack initiation. It is important to note that under the applied loading conditions isolated voids or microcracks were not observed.

Based on the quantitative microscopical investigation an initiation value $J_{i}$ of $160 \mathrm{~N} / \mathrm{mm}$ has been calculated, which is only insignificantly above the static initiation value of the J-integral (Fig. 8).

Due to the highly transient loading with rise times in the order of $10 \mu \mathrm{s}$ the commonly used constitutive equations (e.g. viscoplasticity according to Perzyna, Bodner-Partom) are not suited for the numerical simulations. Especially the strong loading rate dependence of the upper yield point (Fig. 9 [3]) has to be taken into account. This has a pronounced effect on the development of the plastic zone at the crack tip. In this way it was found a good agreement between the FE-calculations of plastic deformation around the loaded crack tip (Fig. 2) and recrystallisation experiments.

\section{ACKNOWLEDGEMENT}

This work was supported by the Bundesminister für Forschung und Technologie under Contract 1500851.

\section{REFERENCES}

[1] Stroppe H., Clos R. and Schreppel U., Nucl. Engng. Des. 137 (1992) 315-321.

[2] Clos R. et al., "Rißverhalten bei Spannungswellenbelastung", BMFT-Report No. 1500 851, 1993.

[3] Kußmaul K., Clos R. et al., "Ermittlung des Einflusses der Beanspruchungsgeschwindigkeit auf das Initiierungsverhalten von Rissen", DFG-Report No. Ku 260/33-1, Str 379/1-1, 1993.

Table 1 Chemical composition

\begin{tabular}{|l|l|l|l|l|l|l|l|l|l|l|l|}
\hline$\% \mathrm{C}$ & $\% \mathrm{Si}$ & $\% \mathrm{Mn}$ & $\% \mathrm{P}$ & $\% \mathrm{~S}$ & $\% \mathrm{Cr}$ & $\% \mathrm{Mo}$ & $\% \mathrm{Ni}$ & $\% \mathrm{Al}$ & $\% \mathrm{Cu}$ & $\% \mathrm{~V}$ & $\% \mathrm{Sn}$ \\
\hline 0.20 & 0.22 & 1.32 & 0.01 & 0.002 & 0.02 & 0.49 & 0.69 & 0.022 & 0.02 & 0.01 & 0.002 \\
\hline
\end{tabular}




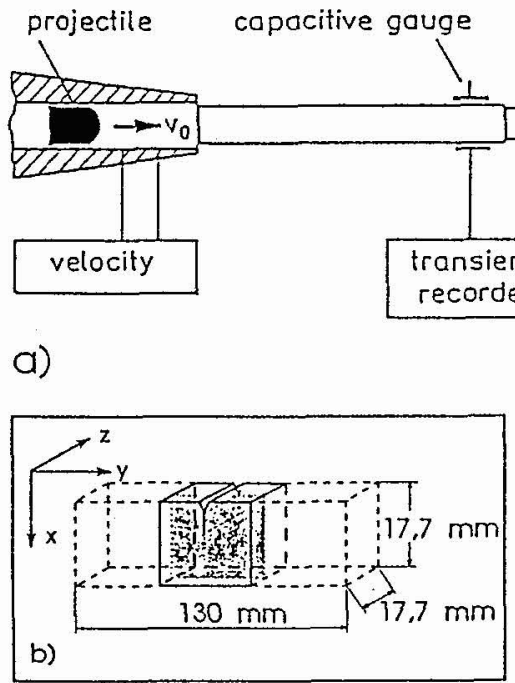

detail A

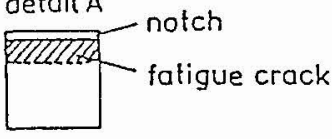
specimen

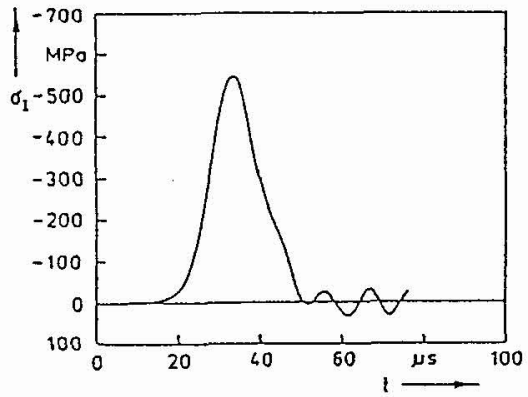

Figure 1 Pulse loading setup (a), size of specimen and preparation coordinate system (b) schematically

\section{AAR@US}

displacement magnification factor $=22.8$

time completed in this step 24.0

total accumulated time 24.0

Figure 2 Loaded 3D - FE specimen 


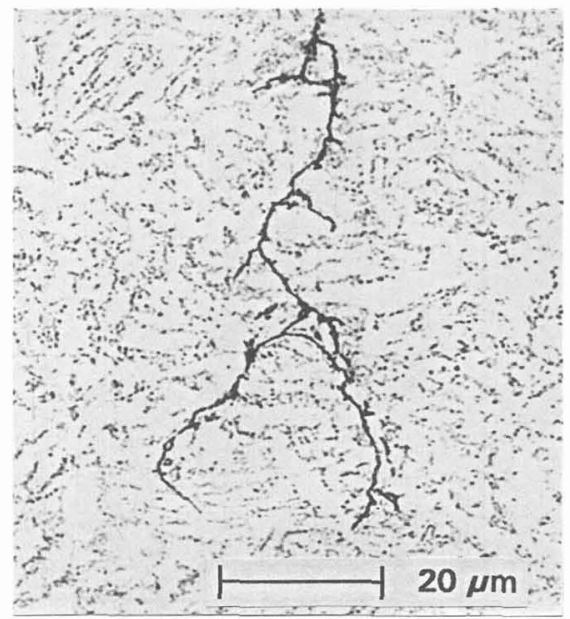

Figure 3 Micrograph of a typical fatigue crack tip

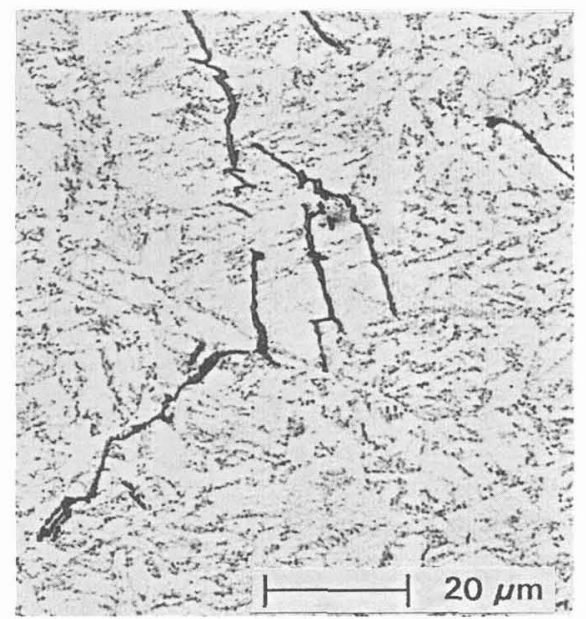

Figure 4 Ensemble of microcracks

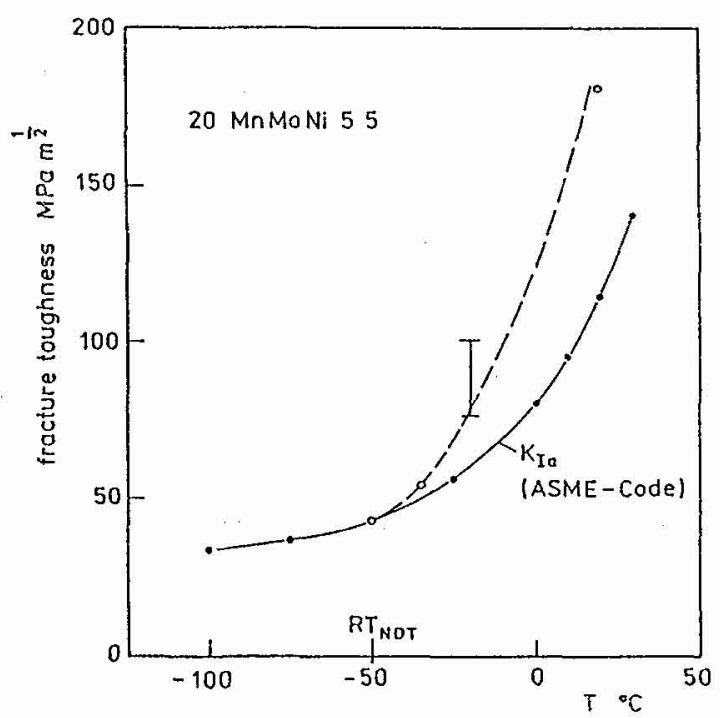

Figure 5 Fracture toughness vs. temperature 


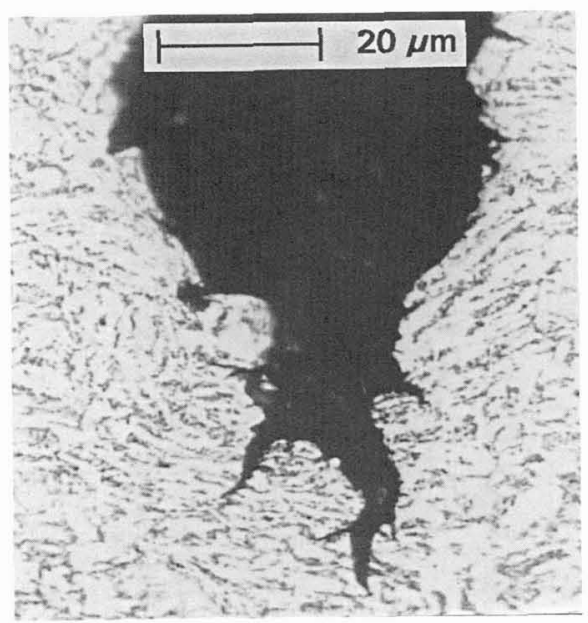

Figure 6 Micrograph shows the blunting effect

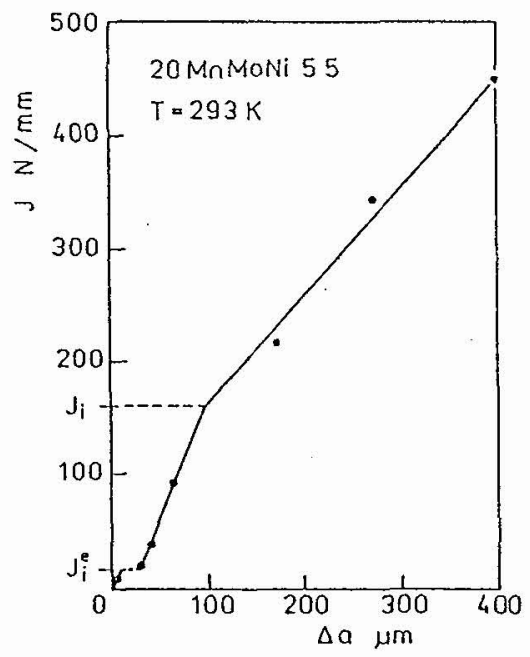

Figure $8 \mathrm{~J}-\Delta$ a curve

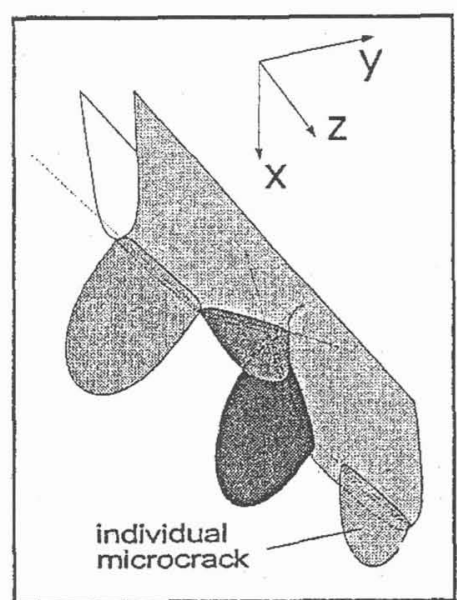

Figure 7 3D- reconstruction of crack front schematically

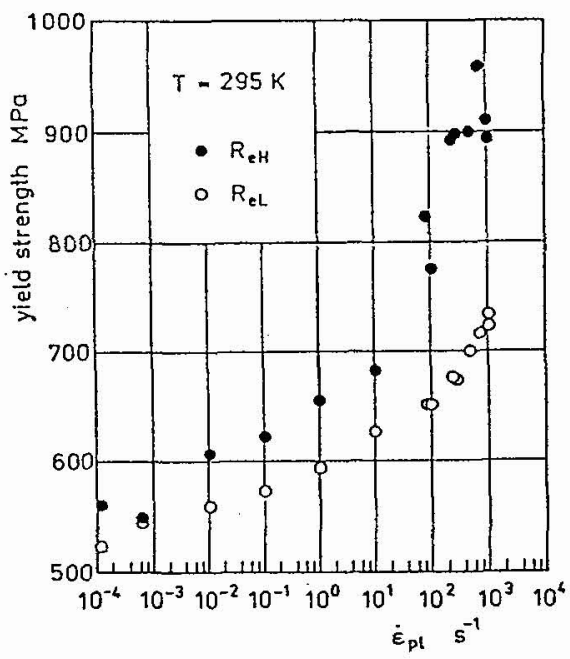

Figure 9 Upper yield strength $\mathrm{R}_{\mathrm{eH}}$ and lower yield strength $R_{\mathrm{cL}}$ as a function of the plastic strain rate 